\title{
TANGGUNG JAWAB NEGARA DALAM PENYELESAIAN PELANGGARAN HAK ASASI MANUSIA ${ }^{1}$
}

\author{
Oleh: \\ Luh Putu Sela Septika ${ }^{2}$
}

\begin{abstract}
The existence of violation on human rights automatically raises the state responsibility to resolve based on laws and regulations. The problem in this research is how the settings related to the completion of state responsibility for human rights violation in the laws and regulations in Indonesia and how efforts to resolve the human rights violation committed by the state actors? This research is normative legal research that using the statute and the conceptual approach. Article 28 paragraph (4) states that the protection, promotion, enforcement and fulfillment of human rights is the responsibility of the state. Article 28 paragraph (4) of Indonesian Constitution and Article 71 Law No. 39 of 1999 regulatesthe rights the state responsibility to protect human rights. Severe human rights violation be tried in the special court of human rights, while the common human rights violation tried in public court, military court or administration court.
\end{abstract}

Keywords: Human Rights, State Responsibility, Violation on Human Rights

\begin{abstract}
Abstrak
Adanya pelanggaran hak asasi manusia secara otomatis memunculkan tanggung jawab negara untuk melakukan upaya penyelesaian sesuai peraturan perundanganundangan. Permasalahan dalam penelitian ini adalah bagaimanakah pengaturan tanggung jawab negara terkait penyelesaian pelanggaran hak asasi manusia dalam peraturan perundang-undangan di Indonesia serta bagaimanakah upaya penyelesaian pelanggaran hak asasi manusia yang dilakukan oleh state actors? Penelitian ini adalah penelitian hukum normatif dengan menggunakanjenis pendekatan yaknipendekatan perudang-undangan dan pendekatan konseptual. Pasal 28I ayat (4) UUD NRI Tahun 1945 dan Pasal 71 UU No. 39 Tahun 1999 mengamanatkan tanggung jawab negara terhadap perlindungan hak asasi manusia. Pelanggaran berat hak asasi manusia diadili di Pengadilan HAM, sedangkan pelanggaran biasa hak asasi manusia diadili di peradilan umum, peradilan militer, dan peradilan tata usaha negara.

\section{Kata kunci: Hak Asasi Manusia, Tanggung Jawab Negara, Pelanggaran HAM}

1 Artikel ini merupakan karya ilmiah mahasiswa pada Program Studi Magister (S2) Ilmu Hukum Program Pascasarjana Universitas Udayana dan mengucapkan terimakasih kepada Prof. Dr. I Gusti Ngurah Wairocana, SH., MH dan Dr. I Gede Yusa, SH., MH selaku Pembimbing Tesis.

2 Penulis adalah mahasiswa magister ilmu hukum Universitas Udayana, Denpasar, Bali, email: selaseptika@yahoo.co.id
\end{abstract}




\section{PENDAHULUAN}

Orde reformasi yang dimulai pada tahun 1998 berusaha menegakkan Hak Asasi Manusia (HAM) dengan jalangmembuat peraturan perundangundangan terkait dengan HAM sebagai rambu-rambu, seperti Undang-Undang No. 39 Tahun 1999 tentang Hak Asasi Manusia (selanjutnya disebut UU No. 39/1999) dan Undang-Undang No. 26 Tahun 2000 tentang Pengadilan Hak Asasi Manusia (selanjutnya disebut UU No. 26/2000). ${ }^{3}$ Pelembagaan instrumen hak asasi manusia juga meningkat ke dalam substansi Undang-Undang Dasar hasil amandemen.

Pemerintah Indonesia juga meratifikasi International Covenant on Economic, Social and Cultural Rights (ICESR)dan International Covenant on Civil and Political Rights (ICCPR) pada 28 Oktober 2005. ICESCR disahkan menjadi Undang-Undang No. 11 Tahun 2005, sedangkan ICCPR menjadi UndangUndang No. 12 Tahun 2005. Selain bertugas mengimplementasikan kedua instrumen internasional tersebut, pemerintahjugaharusmembuatlaporan yang bertalian dengan penyesuaian hukum, langkah-langkah, kebijakan dan tindakan yang dilakukan. ${ }^{4}$

3 Woro Winandi, 2009, Reformasi Penegakan Hak Asasi Manusia di Era Globalisasi. Dalam: Muladi, Editor. Hak Asasi Manusia: Hakekat, Konsep dan Implikasinya dalam Perspektif Hukum dan Masyarakat, PT Refika Aditama, Bandung, hlm. 51

4 Butje Tampi, Mekanisme Pengaduan dan Pelaporan Terhadap Pelanggaran Hak Asasi Manusoa di Indonesia.SERVANDA Jurnal Ilmiah Hukum, http://repo.unsrat.
Pemerintahdalam hal ini sebagai perwujudan negara adalah tepat mengambil tindakan untuk memberikan perhatian lebih terhadap HAM melalui pembentukan peraturan perundang-undangan dan ratifikasi beberapa instrumen internasional di bidang HAM. Sebagaimana termaktub dalam Undang-Undang Dasar Negara Republik Indonesia Tahun 1945 (selanjutnya disebut UUD NRI Tahun 1945) bahwa negara Indonesia adalah negara hukum (Pasal 1 ayat (3)), sehingga sebagai konsekuensinya menjamin adanya perlindungan dan pengakuan terhadap HAM. ${ }^{5}$ Pemahaman lain yang dapat dielaborasi adalah bahwa eksistensi HAM merupakan tanggung jawab negara dalam melindungi segenap bangsa Indonesia sebagaimana disebutkan dalam Pembukaan UUD NRI Tahun 1945.

Namun, keberadaan peraturan perundang-undangan yang mengatur tentang HAM bukanlah jaminan bahwa tidak akan ada pelanggaran HAM, baik dalam kategori berat atau bukan. Pemerintah sebagai perwujudan negara dalam memberikan perlindungan dan penegakan terhadap HAM tidak sepenuhnya mampu mengontrol setiap warga negaranya agar tidak melakukan pelanggaran HAM. Hal inilah yang

ac.id/76/1/MEKANISME PENGADUAN DAN_PELAPORAN TERHADAP PEL ANGARAN_HAK_ASASI MANUSIA_DI_INDONESIA.pdf. diakses tanggal 20 Oktober 2016

5 Ridwan HR, 2010, Hukum Administrasi Negara, Rajawali Press, Jakarta, hlm. 3 
memberikan pemahaman bahwa pelanggaran HAM dapat terjadi kapan, dimana, dan terhadap siapa saja.

Sebagaimana dikutip dari artikel yang dimuat secara online, dinyatakan bahwa penegakan dan pemenuhan HAM di Indonesia masih berada pada tataran memprihatinkan. Keprihatinan tersebut terungkap secara tegas dalam laporan yang disampaikan oleh tiga lembaga HAM nasional, yaitu Komisi Nasional Hak Asasi Manusia (Komnas HAM), Komisi Nasional Perempuan dan Komisi Perlindungan Anak Indonesia (KPAI). Laporan disampaikan dalam sidang HAM yang berlangsung di Jakarta. Masingmasing lembaga HAM mengangkat tema khusus,yaitu isu intoleransi beragama; tema pemiskinan dan kekerasan terhadap perempuan; mengenai kekerasan seksual dan pornografi anak.Tema-tema yang diangkat salah satunya mendasarkan pada pertimbangan bahwa negara seolah tidak turun tangan untuk menyelesaikan pelanggaran atas HAM. $^{6}$

Salah satu pelanggaran HAM yang terjadi di tahun 2016 adalah kasus pemerkosaan dan pembunuhan terhadap siswi Sekolah Menengah Atas di Bengkulu yang bernama Yuyun. Korban diperkosa dan kemudian dibunuh oleh 14 (empat belas) orang

6 Ady, Penegakan HAM di Indonesia Memprihatinkan, http://www.hukumonline. com/berita/baca/lt52aa8fl6e $5 \mathrm{~d} /$ penegakanham-di-indonesia-memprihatinkan, diakses pada tanggal 20 Oktober 2016 pemuda yang rata-rata masih di bawah umur. Kasus ini telah dilimpahkan ke Pengadilan Negeri Rejanglebong (Bengkulu) dan putusannya adalah menjatuhkan hukuman 20 (dua puluh) tahun penjara kepada 4 (empat) orang terdakwa, hukuman mati kepada seorang terdakwa, serta hukuman rehabilitasi bagi yang berumur 13 (tiga belas) tahun. ${ }^{7}$

Masalah perbudakan juga merupakan pelanggaran HAM yang hingga saat ini prakteknya masih terjadi terhadap warga negara Indonesia yang berada di dalam dan di luar negeri. Perbudakan di Indonesia telah dihapuskan setelah tahun 1980, namun pemerintah belum mampu menghentikannya karena berbagai keterbatasan. Perlakuan para majikan yang semena-mena, bahkan tidak manusiawi terhadap pembantu rumah tangga adalah bentuk pelanggaran HAM. $^{8}$

Kasus di atasmerupakan dua diantara sekian banyak kasus pelanggaran terhadap hak hidup, hak atas rasa aman, dan hak untuk tidak disiksa sebagaimana diatur dalam Pasal 28A, Pasal 28G ayat (1) dan Pasal 28I ayat (1) UUD NRI Tahun

7 Rofiq Hidayat, Vonis Mati Satu Pelaku Pemerkosa Yuyun,DianggapBelumMemenuhi Rasa Keadilan, http://www.hukumonline. com/berita/baca/lt57ee193a24fe4/vonis-matisatu-pelaku-pemerkosa-yuyun--dianggapbelum-memenuhi-rasa-keadilan, diakses pada tanggal 20 Oktober 2016

8 Rhona K.M. Smith, et.al, 2010, Hukum Hak Asasi Manusia, Pusat Studi Hak Asasi Manusia Universitas Islam Indonesia (PUSHAM UII), Yogyakarta, hlm. 262 
1945. Penegakan dan perlindungan terhadap hak-hak tersebut yang dikategorikan kedalam hak-hak sipil dan politik sudah semestinya mendapatkan perhatian khusus pemerintah. Tindakan yang bersifat antisipasi maupun penanggulangan atas pelanggaran HAM merupakan dua hal yang sama pentingnya. Melalui tindakan antisipasi diharapkan mampu menurunkan tingkatpelanggaranHAM, sedangkan tindakan penanggulangan diharapkan dapat memberikan rasa aman, keadilan, memulihkan kejiwaan korban, meredam konflik, dan penghormatan terhadap HAM yang diakui eksistensinya.

Berdasarkan latar belakang di atas, maka dapat dikemukakan dua permasalahan yang akan dikaji dalam penelitian ini, yaitu bagaimanakah pengaturan tanggung jawab negara terkait penyelesaian pelanggaran hak asasi manusia dalam peraturan perundang-undangan di Indonesia dan bagaimanakah upaya penyelesaian pelanggaran hak asasi manusia yang dilakukan oleh state actors? Jenis penelitian yang dipergunakan dalam penulisan ini adalah penelitian hukum normatif dengan pendekatan perundang-undangan dan pendekatan konseptual.

Penelitian ini dilakukan melalui penelusuran bahan hukum, baik berupa peraturan perundangundangan maupun literatur hukum yang terkait dengan permasalahan yang akan dikaji dalam penelitian ini.
Namun, Penulis menyadari bahwa terdapat beberapa tulisan ilmiah lain yang memiliki bahasan hampir sama dengan penelitian ini yaitu berkaitan dengan Tanggung Jawab Negara dalam Penyelesaian Pelanggaran Hak Asasi Manusia, antara lain:

Pertama, penelitian pada tahun 2013 yang berjudul "Penyelesaian Perkara Pelanggaran Hak Asasi Manusia (HAM) Berat Prajurit Tentara Nasional Indonesia (TNI)" oleh Jootje Jafet Rares dari Universitas Sam Ratulangi Manado. Tujuan dari penelitiannya adalah untuk mengetahui perbuatan yang dilakukan oleh prajurit, di bawah komando dan pengendalian atau di bawah kekuasaan yang efektif dapat dibuktikan telah memenuhi unsur-unsur pelanggaran hak asasi manusia yang berat. Penyelesaian perkara pelanggaran hak asasi manusia yang berat terhadap prajurit Tentara Nasional Indonesia yang melakukan pelanggaran HAM yang berat di bawah kekuasaan yang efektif oleh komandan militer melalui mekanisme penyelidikan, penyidikan, penuntutan dan pemeriksaan di pengadilan akan menimbulkan pertanggungjawaban pidana baik terhadap prajurit TNI maupun pertanggungjawaban pidana komandan militer.

Kedua, penelitian pada tahun 2004 yang berjudul "Penyelesaian Pelanggaran Hak Asasi Manusia yang Berat; Belajar dari Pengalaman" oleh Asmara Nababan dari Komisi Nasional Hak Asasi Manusia. Tujuan 
dari penelitiannya adalah untuk menguraikan beberapa persoalanpersoalan menyangkut konsep pelanggaran hak asasi manusia yang berat, tanggung jawab individu dalam kejahatan internasional, elemenelemen kejahatan pelanggaran hak asasi manusia, konsep tanggungjawab komando dan mekanisme penyelesaian kejahatan pelanggaran hak asasi manusia.

Ketiga, penelitian pada tahun 2015 yang berjudul "Tanggung Jawab Negara terhadap Kerugian Wisatawan Berkaitan dengan Pelanggaran Hak Berwisata sebagai Bagian dari Hak Asasi Manusia" oleh Putu Eva Laheri dari Universitas Udayana. Tujuan dari penelitiannya adalah untuk mengetahui secara konseptual wisatawan dapat mengajukan tuntutan ganti rugi kepada negara atas dilanggarnya hak berwisata yang dimiliki oleh wisatawan tersebut, serta untuk mengetahui tuntutan ganti rugi tersebut dapat diajukan ketika wisatawan mampu membuktikan bahwa negara telah melakukan pelanggaran hak sebagaimana diuraikan dalam Pedoman Maastricht dan negara tidak mampu membuktikan jika pelanggaran tersebut terjadi karena negara dalam keadaan bahaya atau darurat.

Keempat, penelitian pada tahun 2013 yang berjudul "Tanggung Jawab Pemerintah Terhadap Pelanggaran Hak AsasiManusiaTenagaKerjaIndonesia" oleh Edward Richard J. Pinoke dari Universitas Sam Ratulangi. Tujuan penelitiannya adalah untuk mengetahui tanggung jawab negara terhadap pelanggaran hak asasi manusia tenaga kerja Indonesia berdasarkan aturan hukum internasional dan aturan hukum nasional.

Perbedaan penelitian ini dengan keempat penelitian yang telah dipaparkan di atas terletak pada fokus kajiannya. Kajian dalam penelitian ini berpusat pada pengaturan dan bentuk tanggung jawab negara dalam menyelesaikan pelanggaran HAM biasa maupun berat berdasarkan peraturan perundang-undangan yang berkaitan dengan HAM.

Adapun yang menjadi tujuan dari penelitian ini adalah untuk mengetahui pengaturan tanggung jawab negara dalam peraturan perundangundangan terkait dengan penyelesaian pelanggaran HAM, serta memberikan gambaran yang jelas tentang upaya penyelesaian pelanggaran HAMyang dilakukan oleh negara. Tanggung jawab negara yang dimaksud dalam penelitian ini adalah tanggung jawab yang muncul akibat terjadinya pelanggaran HAM.

\section{METODE PENELITIAN}

Jenis penelitian yang digunakan dalam penulisan ini adalah jenis penelitian hukum normatif atau disebut juga penelitian hukum kepustakaan. Soerjono Soekanto dan Sri Mamuji menyajikan pengertian penelitian hukumnormatifyaknipenelitianhukum yang dilakukan dengan cara meneliti 
bahan pustaka ${ }^{9}$ atau penelitian yang berlandaskan pada ketentuan hukum dalam peraturan perundang-undangan yang berlaku, ${ }^{10}$ dan kemudian dikaitkan dengan permasalahan yang dikaji. Jenis pendekatan yang digunakan adalah pendekatan konseptual dan pendekatan perudang-undangan. ${ }^{11}$

\section{HASIL DAN PEMBAHASAN}

3.1. Pengaturan Tanggung Jawab Negara dalam Peraturan Perundang-undangan Terkait Penyelesaian Pelanggaran Hak Asasi Manusia

Indonesia adalah negara hukum yang berarti bahwaseluruh penyelenggaraan negara berdasarkan atas hukum, di mana peraturanperaturan hukum berlaku terhadap segala badan atau alat-alat perlengkapan negara. Definisi negara hukum ini dicermati melalui tulisan Soepomo “...bahwa Republik Indonesia dibentuk sebagai negara hukum." dalam bukunya yang berjudul Undang-Undang Dasar Sementara dengan Komentar Pasal-pasalnya. ${ }^{12}$ Negara hukum memberikan perlindungan hukum kepada masyarakat di mana antara hukum dan

9 Salim HS dan Erlies Septiana Nurbani, 2013, Penerapan Teori Hukum pada Penelitian Tesis dan Disertasi, PT RajaGrafindo Perkasa, Jakarta, hlm. 12

10 Peter Mahmud Marzuki, 2005, Penelitian Hukum, Fajar Interpratama Offset, Jakarta, hlm. 93

11 Salim HS dan Erlies Septiana Nurbani, op.cit., hlm. 17

12 I Dewa Gede Atmadja, 2015, Teori Konstitusi dan Konsep Negara Hukum, Setara Press, Malang, hlm. 124 kekuasaan terdapat hubungan timbal balik. Hal ini bermakna bahwa negara hukum memberikan jaminan untuk terselenggaranya tertib hukum dalam tatanan kehidupan masyarakat. ${ }^{13}$

Selanjutnya, jaminan atas perlindungan HAM merupakan salah satu ciri penting dari negara hukum seperti yang dikemukakan oleh Jimly Asshiddiqie, ${ }^{14}$ selain diterapkannya asas legalitas, pembagian kekuasaan, dan adanya peradilan administrasi negara. Secara khusus dalam UUD NRI Tahun 1945 telah diatur bab khusus mengenai pengaturan HAM yakni Pasal 28A - 28J. Pengaturan ini memberikan pemahaman bahwa HAM merupakan hak konstitusional yang dijamin dan dilindungi oleh konsitusi.

Pasal 1 angka 1 UU No. 39/1999 menyebutkan: "Hak Asasi Manusia adalah seperangkat hak yang melekat pada hakikat dan keberadaan manusia sebagai mahkluk Tuhan Yang Maha Esa dan merupakan anugerah-Nya yang wajib dihormati, dijunjung tinggi dan dilindungi oleh negara, hukum dan Pemerintah, dan setiap orang demi kehormatan serta perlindungan harkat dan martabat manusia." Ketentuan pasal tersebut menegaskan kembali bahwa negara maupun pemerintah memiliki kewajiban untuk melindungi HAM yang berkedudukan sebagai hak dasar.

\footnotetext{
13 Ibid.

14 Jimly Asshidiqie, 2007, Pokok-pokok Hukum Tata Negara Indonesia Pasca Reformasi, PT Bhuana Ilmu Populer, Jakarta, hlm. 310
} 
Pelanggaran HAM dapat dilakukan oleh seseorang atau kelompok orang termasuk di dalamnya adalah aparat negara yang didasarkan pada kesengajaan atau ketidak sengajaan. Kelalaian secara melawan hukum berupa mengurangi, menghalangi, membatasi, dan atau mencabut HAM sebagaimana dijamin oleh UU No. 39/1999 dikategorikan sebagai pelanggaran, bahkan dalam haltidak mendapatkan atau dikhawatirkan tidak memperoleh penyelesaian hukum yang adil dan benar sesuai mekanisme hukum termasuk dalam pelanggaran (Pasal 1 angka 6 UU No. 39/1999).

Dilihat dari segi hubungan hukum dan HAM, maka pada prinsipnya pelanggaran HAM adalah pelanggaran hukum.Namun, seringkali terjadi perbedaan pendapat dalam mengkualifikasi pelanggaran HAM berat dan pelanggaran HAM biasa. Pelanggaran HAM berat yang dirumuskan dalam Pasal 7 UU No. 26/2000meliputi kejahatan genosida dan kejahatan terhadap kemanusiaan. Rumusan delik pelanggaran HAM berat dalam Pasal 7 UU No. 26/2000 berasal dari rumusan Pasal 6 dan7 Rome Statute of International Criminal Court (Statuta Roma) yang kualifikasi perbuatannya memiliki hal-hal yang bersifat spesifik yang membedakannya dengan tindak pidana umum. ${ }^{15}$

Rumusan Pasal 8 UU No. 26/2000 tentang kejahatan genosida:

15 Ibid., hlm. 106
Setiap perbuatan yang dilakukan dengan maksud untuk menghancurkan atau memusnahkan seluruh atau sebagian kelompok bangsa, ras, kelompok etnis, kelompok agama, dengan cara:

a. membunuh anggota kelompok;

b. mengakibatkan penderitaan fisik dan mental yang berat terhadap anggota-anggota kelompok;

c. menciptakan kondisi kehidupan kelompok yang akan mengakibatkan kemusnahan secara fisik baik seluruh atau sebagiannya;

d. memaksakan tindakan-tindakan yang bertujuan mencegah kelahiran di dalam kelompok; atau

e. memindahkan secara paksa anakanak dari kelompok tertentu ke kelompok lain.

Pasal 9 tentang kejahatan terhadap kemanusiaan:

Salah satu perbuatan yang dilakukan sebagai bagian dari serangan yang meluas atau sistematik yang diketahuinya bahwa serangan tersebut ditujukan secara langsung terhadap penduduk sipil, berupa:

a. pembunuhan;

b. pemusnahan;

c. perbudakan;

d. pengusiran atau pemindahan penduduk secara paksa;

e. perampasan kemerdekaan atau perampasan kebebasan fisik lain secara sewenang-wenang yang melanggar (asas-asas) ketentuan 
pokok hukum internasional;

f. penyiksaan;

g. perkosaan, perbudakan seksual, pelacuran secara paksa, pemaksaan kehamilan, pemandulan atau sterilisasi secara paksa atau bentuk-bentuk kekerasan seksual lain yang setara;

h. penganiayaan terhadap suatu kelompok tertentu atau perkumpulan yang didasari persamaan paham politik, ras, kebangsaan, etnis, budaya, agama, jenis kelamin atau alasan lain yang telah diakui secara universal sebagai hal yang dilarang menurut hukum internasional;

i. penghilangan orang secara paksa; atau

j. kejahatan apartheid.

Berdasarkan rumusan pasalpasal di atas, maka pelanggaran HAM berat merupakan jenis pelanggaran yang dilakukan oleh penguasa negara (state actors) atau organisasi/ kelompok yang terorganisir,serta tindakannya memiliki dampak yang luas atau dilakukan secara sistematik. Sedangkan, pelanggaran HAM biasa adalah pelanggaran yang dilakukan oleh kelompok masyarakat atau individu tertentu terhadap individu atau kelompok masyarakat lain dan diadili di Peradilan Umum. ${ }^{16}$

Agar dapat dinyatakan sebagai

16 Ni Ketut Sri Utari, et.al., 2016, Buku Ajar Hukum Hak Asasi Manusia, Fakultas Hukum Universitas Udayana, Denpasar, hlm. 100 pelanggaran HAM biasa, maka tindak pidananya harus memenuhi unsurunsur tindak pidana umum. Unsur obyektif yakni perbuatan pidana/actus reus yang meliputi: adanya perbuatan yang memenuhi rumusan undangundang; bersifat melawan hukum; dan tidak ada alasan pembenar. Sedangkan, unsur subyektif berkenaan dengan pertanggungjawaban pidana/criminal responsibility.

Terkait dengan kejahatan terhadap kemanusiaan dan kejahatan HAM berat lainnya, maka unsurunsur kejahatan/the elements of crime terdiri atas unsur material dan unsur mental. Unsur material yakni adanya perbuatan (conduct), adanya akibat-akibat yang ditimbulkan dari perbuatan tersebut (consequences) dan adanya keadaan-keadaan yang menyertai perbuatan tersebut. Unsur mental terdiri atas unsur kesengajaan dan adanya pengetahuan. ${ }^{17}$

Pasal 30 Statuta Roma menentukan adanya kesengajaan apabila sehubungan dengan perbuatan (conduct) tersebut, si pelaku berniat untuk melakukan atau turut serta melakukan perbuatan tersebut. Berkaitan dengan akibatnya (consequences), si pelaku berniat untuk menimbulkan akibat tersebut atau sadar bahwa pada umumnya akan terjadi dalam kaitan dengan perbuatan tersebut. Sedangkan, pengetahuan (knowledge) diartikan sebagai kesadaran terhadap suatu keadaan atau

17 Ibid., hlm. 109 
akibat yang akan timbul.

Perlu diperhatikan pula mengenai elemen kejahatan terhadap kemanusiaan dalam hal mana perbuatan terjadi, yaitu (1) perbuatan tersebut dilakukan sebagai bagian dari serangan yang meluas atau sistematik ditujukan pada penduduk sipil; (2) keharusan adanya pengetahuan pelaku bahwa perbuatan yang dilakukan merupakan bagian dari atau dimaksudkan untuk menjadi bagian dari serangan yang meluas dan sistematis terhadap penduduk sipil.

Kualifikasi seranganyangmeluas mengandung dimensi kuantitatif/ besar/banyak atau skala luas: nasional/ regional/internasional, bukan perkara pelaku perseorangan terhadap orang lain (isolated crime). Membunuh satu orang saja bisa dianggap pelanggaran HAM yang berat, asal perbuatan itu merupakan bagian dari serangan yang meluas yang ditujukan pada penduduk sipil. Kualifikasi sistematik maksudnya bahwa adanya bentuk rencana yang terpola atau metodis dan jelas dari sebuah kebijaksanaan (policy). Sehingga, perbuatannya berencana, terorganisir dan akibatnya adalah luas. ${ }^{18}$

Penyelesaian pelanggaran HAM sudah sepatutnya diutamakan sebagai bentuk penegakan dan perlindungan HAM. Pada prinsipnya, penegakan hak-hak yang berkaitan dengan hak sipil dan politik merupakan tanggung jawab negara yang bersifat mutlak

18 Ibid., hlm. 110 dan mengikat. Artinya, apabila terjadi pelanggaran terhadap hak-hak tersebut, maka negara menjadi satu-satunya pihak yang berkewajiban menjaga dan melindunginya sebab hak sipil dan politik bersifat universal. ${ }^{19}$ Berkenaan dengan tanggung jawab negara ini, maka pengaturannya dalam hukum positif Indonesia dijumpai padaUUD NRI Tahun 1945, UU No. 39/1999, dan UU No. 26/2000.

Rumusan pasal-pasal dalam UUD NRI Tahun 1945 secara khusus tidak ada yang menyebutkan tentang bentuk tanggung jawab negara dalam penyelesaian HAM. Hanya saja disebutkan tanggung jawab negara secara umum, terutama pemerintah dalam perlindungan, pemajuan, penegakan, dan pemenuhan hak asasi manusia. ${ }^{20}$ Dalam rangka melindungi dan menegakkan HAM, maka pemerintah membentuk peraturan perundang-undangan yang berkaitan dengan HAMdi bawah UUD NRI Tahun 1945. Peraturan perundangundangan yang akan dibentuk itu diharapkan mampu memberikan pengaturan lebih mengkhusus terhadap perlindungan HAM. ${ }^{21}$

Pengaturan tanggung jawab negara secara tidak langsung ditunjukkan pula oleh Pasal 30 ayat (4) UUD NRI Tahun 1945 yang

\footnotetext{
19 Ibid., hlm. 87.

20 Pasal 28I ayat (4) Undang-Undang Dasar Negara Republik Indonesia Tahun 1945 dan Pasal 8 Undang-Undang No. 39 Tahun 1999 tentang Hak Asasi Manusia

21 Pasal 28I ayat (5) Undang-Undang Dasar Negara Republik Indonesia Tahun 1945
} 
menyebutkan: "Kepolisian Negara Republik Indonesia sebagai alat negara yang menjaga keamanan dan ketertiban masyarakat bertugas melindungi, mengayomi, melayani masyarakat, sertamenegakkanhukum."Pemahaman atas ketentuan pasal tersebut, bahwa Kepolisian Negara Republik Indonesia merupakan alat negara, sehingga tanggung jawab negara dibebankan kepada pihak kepolisian. Tugas melindungi, mengayomi, melayani masyarakat, dan menegakkan hukum apabila dielaborasi, maka tidak hanya berfokus pada bidang pertahanan dan keamanan saja, melainkan menyentuh pula ranah HAM. Tindakan kepolisian seperti melakukan penyelidikan atas pelanggaran hukum tertentu, mengatasi terorisme, pengawalan kegiatan demonstrasi, maupun tindakan lainnya merupakan bagian dari perlindungan dan penegakan HAM.

Realisasi dari Pasal 28I ayat (5) UUD NRI Tahun 1945 mengenai pelaksanaan HAM yang dijamin dan diatur dalam peraturan perundang-undangan yakni dengan pembentukan dan pemberlakuan UU No. 39 Tahun 1999. Undang-undang ini menentukan bahwa pemerintah wajib dan bertanggung jawab terkait usahanya menghormati, melindungi, menegakkan, dan memajukan hak asasi manusia. ${ }^{22}$ Kewajiban dan tanggung jawab pemerintah tersebut meliputi langkah implementasi dalam

22 Pasal 71 Undang-Undang No. 39 Tahun 1999 tentang Hak Asasi Manusia bidang hukum, politik, ekonomi, sosial, budaya pertahanan keamanan negara, dan bidang lain. ${ }^{23}$ Keberadaan undang-undang ini menjadi tonggak dibentuknya pengadilan hak asasi manusia di lingkungan Peradilan Umum sebagai upaya mengadili pelanggaran hak asasi manusia (Pasal 104 ayat (1)). Sehingga pada tanggal 23 November 2000 disahkan UU No. 26 Tahun 2000 tentang Pengadilan Hak Asasi Manusia. ${ }^{24}$

Tanggung jawab negara dalam UU No. 39/1999 diwujudkan pula melalui keberadaan Komisi Nasional Hak Asasi Manusia (Komnas HAM). Komnas HAM adalah lembaga mandiri yang kedudukannya setingkat dengan lembaga negara lainnya yang bertujuan untuk meningkatkan perlindungan dan penegakan hak asasi manusia. ${ }^{25}$ Guna mencapai tujuan tersebut, Komnas HAM melaksanakan fungsi pengkajian, penelitian, penyuluhan, pemantauan, dan mediasi tentang hak asasi manusia sebagaimana di atur oleh Pasal 76 ayat (1) Undang-Undang No. 39 Tahun 1999.

UUNo. 26/2000 dibentuk sebagai pemenuhan Pasal 104 ayat (1) UU No. 39/1999, bahwa perlunya dibentuk suatu Pengadilan Hak Asasi Manusia

23 Pasal 72 Undang-Undang No. 39 Tahun 1999 tentang Hak Asasi Manusia

24 Pasal 104 ayat (2) Undang-Undang No. 39 Tahun 1999 tentang Hak Asasi Manusia: "Pengadilan sebagaimana dimaksud dalam ayat (1) dibentuk dengan undang-undang dalam jangka waktu paling lama 4 (empat) tahun."

25 Pasal 75 ayat (2) Undang-Undang No. 39 Tahun 1999 tentang Hak Asasi Manusia 
untuk menyelesaikan pelanggaran HAM berat. UU No. 26/2000 menganut asas non-retroaktif, sehingga hanya dapat mengadili pelanggaran hak asasi manusia yang terjadi setelah undang-undang ini diberlakukan, yaitu setelah tahun 2000. Pengadilan HAM bertempat di 4 (empat) kota besar di Indonesia, diantaranya Medan, Jakarta, Surabaya, dan Makassar. ${ }^{26}$ Tempat dan kedudukan Pengadilan HAM yaitu di daerah kabupaten atau kota yang daerah hukumnya meliputi daerah hukum Pengadilan Negeri yang bersangkutan.

UU No. 26/2000 tidak secara tegas mendefinisikan istilah pelanggaran HAM berat, melainkan hanya menyebutkan secara limitatif jenis-jenis perbuatan yang dapat dikualifikasikans ebagai pelanggaran HAM berat, yakni kejahatan genosida dan kejahatan terhadap kemanusiaan. ${ }^{27}$ Walaupun demikian, tetap saja perlindungan HAM menjadi aspek penting yang harus diperjuangkan oleh semua pihak. Ditekankan kembali bahwa tanggung jawab negara ditunjukkan oleh keterlibatan alat perlengkapan negara mulai dari dilakukan penangkapan oleh Penyidik terhadap seseorang yang diduga melakukan pelanggaran hak asasi manusia berat sampai dengan diperiksa dan diputusnya perkara.

26 Rhona K.M. Smith, et.al., op.cit., hlm. 272

27 Pasal 7 Undang-Undang No. 26 Tahun 2000 tentang Pengadilan Hak Asasi Manusia
3.2. Upaya

Penyelesaian

Pelanggaran Hak Asasi

Manusia oleh State Actors

Melindungi kebebasan dan hak asasi setiap orang merupakan tugas negara yang senantiasa dilakukan secara aktif demi terciptanya kesejahteraan rakyat. Lembaga/ badan pemerintahan tidak dapat melakukan tindakan atau perbuatan yang bertentangan dengan konstitusi. Dalam kerangka sebuah negara, konstitusi memuat konsep-konsep dasar dan merupakan ketentuan hukum yang tertinggi, sehingga negara dan konstitusi menjadi dua hal tak terpisahkan. ${ }^{28}$

Konstitusi memberikan arahan yang jelas mengenai tanggung jawab sekaligus tujuan yang hendak diwujudkan oleh negara, khususnya dalam melindungi dan menegakkan HAM. Saat negara/Pemerintah (states actor) melakukan pelanggaran HAM, maka dapat terhadapnya dapat dituntut di Pengadilan HAM Nasional, bahkan Pengadilan Kejahatan Internasional. Dalam tulisan ini akan dibedakan antara penyelesaian pelanggaran HAM berat dan biasa.

Sebagaimana telah diuraikan sebelumnya bahwa perkara pelanggaran HAM dapat dikategorikan menjadi dua macam, yaitu pelanggaran HAM biasa dan pelanggaran berat.

28 Eddy Purnama, 2007, Negara Kedaulatan Rakyat; AnalisisterhadapSistemPemerintahan Indonesia dan Perbandingannya dengan Negara-negara Lain, Nusamedia, Bandung, hlm. 33 
Kriteria dari pelanggaran HAM berat yaitu: menimbulkan kerugian materiil dan immaterial; berdampak secara luas (nasional/regional/internasional); motif perbuatan yang sarat masalah politik; serta kejahatannya merupakan kejahatan terhadap kemanusiaan dan kejahatan genosida. Berdasarkan ciriciri tersebut, maka perkara pelanggaran HAM berat diadili melalui peradilan yang bersifat khusus (Peradilan Hak Asasi Manusia). Sehingga, proses acara pemeriksaan yang diterapkan dalam pelanggaran HAM berat ini sangatlah berbeda dengan hukum acara pidana biasa.

UU No. 26/2000 hadir sebagai peraturan perundang-undangan yang memuat tentang upaya penyelesaian pelanggaran HAM berat.Kejahatan yang diatur dalam UU No. 26/2000 adalah kategoriextra ordinary crimes. UU No. 26/2000 adalah lex specialis dengan konsekuensi bahwa di dalamnya terdapat ketentuan yang menyimpang dari ketentuan yang terdapat dalam KUHP mengenai penerapan asas retroaktif. ${ }^{29}$

Ancaman pidana yang dikenakan terhadap pelaku pelanggaran HAM berat berbeda halnya dengan pelaku pelanggaran HAM biasa. Ancaman sanksi pelanggaran HAM berat diatur dalam Pasal 36 - Pasal 41 UU No. 26/2000. Berdasarkan ketentuan Pasal 41 bahwa ancaman hukuman bagi pelaku dan yang membantu melakukan, percobaan, permufakatan jahat adalah sama.

29 Rhona K.M. Smith, et.al., op.cit., hlm. 309
Dalam perkara pelanggaran HAM berat dikenal juga adanya pertanggungjawaban komando. Berdasarkan ketentuan Pasal 41 ayat (3), seorang komandan/atasan dapat dipidana dengan hukum yang sama dengan anak buahnya walaupun ia tidak melakukan apa-apa. Sumber pertanggungjawaban pidana bagi pemegang komando di lingkungan militer adalah dari kekuasaannya untuk memerintah, mengatur, mengendalikan dan mengawasi tindakan prajurit di bawah komandonya, dalam bentuk delik tidak berbuat dan delik penyalahgunaan wewenang. ${ }^{30}$

Pasal-pasal tentang hukum acara dalam UU No. 26/2000 seluruhnya berjumlah 24 pasal (Pasal 10 - Pasal 33). Diawali olehpasalyang merupakan ketentuan umum yang menetapkan bahwa "Dalam hal tidak ditentukan lain dalam undang-undang ini, hukum acara atas perkara pelanggaran hak asasi manusia yang berat dilakukan berdasarkan ketentuan hukum acara pidana". ${ }^{31}$ Beberapa aturan beracara baru yang diatur dalam UU No. 26/2000 dan mengecualikan aturan yang sama dalam KUHP, diantaranya: (i) pembentukan penyelidik ad hoc, penyidik ad hoc, penuntut ad hoc, dan hakim ad hoc; (ii) penyelidik hanya dilakukan oleh Komnas HAM, sedangkan penyidik tidak diperkenankan menerima laporan atau pengaduan sebagaimana diatur dalam

30 Ni Ketut Sri Utari, et.al., op.cit., hlm. 115

31 Pasal 10 Undang-Undang No. 26 Tahun 2000 
KUHP; (iii) diperlukan ketentuan mengenai tenggang waktu tertentu melakukan penyidikan, penuntutan dan pemeriksaan pengadilan; (iv) ketentuan mengenai korban atau saksi.

Dalam hal penyelidikan pelanggaran HAM berat merupakan kewenanganKomnasHAM, sedangkan penyidikan dan penuntutan dilakukan oleh Jaksa Agung berdasarkan hasil penyelidikan Komnas HAM. UU No. 26/2000 memisahkan lembaga penyelidik dan lembaga penyidik dengan pertimbangan bahwa lembaga yang ditetapkan sebagai lembaga penyidik adalah lembaga yang independen dengan maksud agar hasil penyelidikannya dapat dijamin objektivitasnya. ${ }^{32}$

Pemeriksaan perkara di Pengadilan HAM dilaksanakan paling lama 180 hari, dan dilakukan oleh Majelis Hakim yang terdiri dari 3 hakim ad hoc dan 2 hakim karir yang diketuai oleh Hakim Pengadilan HAM. $^{33}$ Di Pengadilan Tinggi pemeriksaan dilakukan paling lama 90 hari sejak diterimanya berkas perkara, dan majelis hakim terdiri dari 3 hakim ad hoc dan 2 hakim karir. Pemeriksaan di tingkat kasasi harus diselesaikan paling lama 90 hari dengan majelis hakim yang terdiri dari 3 hakim ad hoc dan 2 hakim karir. ${ }^{34}$

Mengenai ketentuan pidana, bagi kejahatan yang diatur dalam Pasal 8

32 Rhona K.M. Smith, et.al., op.cit., hlm. 310

33 Pasal 27 Undang-Undang No. 26 Tahun 2000

34 Pasal 33 Undang-Undang No. 26 Tahun 2000 a,b,c,d,e diancam dengan pidana mati, atau pidana penjara seumur hidup atau pidana penjara selama-lamanya 25 tahun atau sekurangnya 10 tahun. Bagi kejahatan tercantum dalam Pasal 9 a,b,c,d,e atau j, dipidana dengan pidana mati, atau pidana penjara paling singkat 10 tahun. Bagi kejahatan sebagaimana diatur dalam Pasal $9 \mathrm{c}$ atau $\mathrm{f}$, dipidana dengan pidana penjara paling lama 15 tahun dan paling singkat 5 tahun. Bagi kejahatan yang diatur dalam Pasal 9 $\mathrm{g}, \mathrm{h}$, dan i dipidana penjara selamalamanya 20 tahun dan paling singkat 10 tahun.

Pasal 7 sampai dengan Pasal 17 UU No. 26/2000 memberikan kewenangan untuk melakukan penangkapan dan penahanan terhadap tersangka pelaku pelanggaran berat hak asasi manusia dan lama waktu penahanan serta selama proses persidangan dan kasasi ke Mahkamah Agung. Undang-undang ini mengatur mengenai batas waktu maksimal untuk melakukan penahanan sejak tahap penyidikan, penuntutan, pemeriksaan, persidangan, banding, dan kasasi.

Lebih lanjut mengenai pelanggaran HAM biasa, terhadap para pelaku pelanggaran HAM biasa (tidak berat) akan diadili oleh Peradilan Umum (Perdata/Pidana), Peradilan Militer, Peradilan Tata Usaha Negara tergantung pada jenis sifat perkara, baik yang berkaitan dengan pelaku, perbuatan dan akibat yang ditimbulkan dari pelanggaran 
HAM yang dikategorikan biasa. ${ }^{35}$ Pelaku dari pelanggaran HAM biasa adalah perseorangan atau beberapa orang, jumlah korban terbatas, dan motif perbuatannya hanya berkisar pada masalah pribadi/hukum.

Sehubungan dengan adanya pelanggaran berat hak asasi manusia, perlindungan terhadap korban dan saksi adalah tanggung jawab negara pula selain membantu penyelesaian pelanggarannya. Perlindungan saksi tersebut juga mencakup pemberian ganti kerugian bagi korban dan keluarganya termasuk kompensasi, restitusi, dan rehabilitasi. UU No. 26/2000 telah memberikan jaminan perlindungan saksi dan korban seperti diatur dalam Pasal 34 dan Pasal 35. Tata cara pelaksanaannya diatur dalam Peraturan Pemerintah No. 2 Tahun 2002 tentang Perlindungan Korban dan Saksi bagi Pelanggaran Berat Hak Asasi Manusia dan Peraturan Pemerintah No. 3 Tahun 2002 tentang Kompensasi, Restitusi, danRehabilitasi terhadap Korban Pelanggaran Berat Hak Asasi Manusia.

Dapat dipahami bahwa selain penghukuman kepada pelaku, pemberian kompensasi kepada korban merupakan salah satu bentuk tanggung jawab negara ketika terjadi pelanggaran berat hak asasi manusia. Pemberian kompensasi tidak harus menunggu pelaku atau pihak ketiga tidak mampu untuk memenuhi tanggung jawabnya, namun merupakan kewajiban yang

35 Ni Ketut Sri Utari, et.al., op.cit., hlm. 99 sudah melekat bagi negara. ${ }^{36}$ Dengan lain perkataan, dibebaskan atau dihukumnya terdakwa tidak akan mempengaruhi kewajiban negara untuk memberikan kompensasi bagi korban pelanggaran berat hak asasi manusia.

\section{KESIMPULAN}

1. Pelanggaran HAM dikategorikan menjadi dua yakni pelanggaran HAM berat yang dilakukan oleh states actor dengan alasan politik dan pelanggaran HAM biasa yang dilakukan rakyat sipil dilatarbelakangi oleh masalah pribadi/hukum. Atas terjadinya pelanggaran HAM, maka diaturlah tanggung jawab negara untuk menghormati, melindungi, menegakkan, dan memajukan HAM sebagaimana dimuat dalam UUD NRI Tahun 1945 (Pasal 28I ayat (4)), UU No. 39/1999 tentang Hak Asasi Manusia (Pasal 71) dan UU No. 26/2000 tentang Pengadilan Hak Asasi Manusia.

2. Perkara pelanggaran HAM berat diadili oleh Peradilan Hak Asasi Manusia, sedangkan perkara pelanggaran HAM biasa diadili oleh Peradilan Umum (Perdata/ Pidana), Peradilan Militer, Peradilan Tata Usaha Negara tergantung pada jenis sifat perkara, baik yang berkaitan dengan pelaku, perbuatan dan

36 Rhona K.M. Smith, et.al., op.cit., hlm. 314 
akibat yang ditimbulkan. Pelaku pelanggaran HAM biasa adalah perseorangan atau beberapa orang di mana jumlah korban terbatas. Ancaman pidana bagi pelaku pelanggaran HAM berat yakni Pasal 36 - Pasal 41 UU No. 26/2000, sedangkan ancaman pidana bagi pelanggaran HAM biasa disesuaikan dengan KUHP. Berkenaan dengan perkara pelanggaran HAM berat,terdapat pertanggungjawaban komando di mana seorang komandan/atasan dapat dipidana dengan hukuman yang sama dengan anak buahnya walaupun ia tidak melakukan apa-apa (Pasal 41 ayat (3) UU No. 26/2000).

\section{DAFTAR PUSTAKA}

\section{Buku}

Asshidiqie, Jimly, 2007, Pokok-pokok Hukum Tata Negara Indonesia Pasca Reformasi, PT Bhuana Ilmu Populer, Jakarta.

Atmadja, I Dewa Gede, 2015, Teori Konstitusi dan Konsep Negara Hukum, Setara Press, Malang.

HR, Ridwan, 2010, Hukum Administrasi Negara, Rajawali Press, Jakarta.

Marzuki, Peter Mahmud, 2005, Penelitian Hukum, Fajar Interpratama Offset, Jakarta.

Purnama, Eddy, 2007, Negara Kedaulatan Rakyat; Analisis terhadap Sistem Pemerintahan Indonesia dan Perbandingannya dengan Negara-negara Lain, Nusamedia, Bandung.

Rhona K.M. Smith, et.al, 2010, Hukum Hak Asasi Manusia, Pusat Studi Hak Asasi Manusia Universitas Islam Indonesia (PUSHAM UII), Yogyakarta.

Salim HS dan Erlies Septiana Nurbani, 2013, Penerapan Teori Hukum pada Penelitian Tesis dan Disertasi, PT RajaGrafindo Perkasa, Jakarta.

Sri Utari, Ni Ketut, et.al., 2016, Buku Ajar Hukum Hak Asasi Manusia, Fakultas Hukum Universitas Udayana, Denpasar.

Winandi, Woro, 2009, Reformasi Penegakan Hak Asasi Manusia di Era Globalisasi. Dalam: Muladi, Editor. Hak Asasi Manusia: Hakekat, Konsep dan Implikasinya dalam Perspektif Hukum dan Masyarakat, PT Refika Aditama, Bandung.

\section{Peraturan}

\section{Perundang-undangan}

Undang-Undang Dasar Negara Republik Indonesia Tahun 1945

Undang-Undang Nomor 39 Tahun 1999 tentang Hak Asasi Manusia (Lembaran Negara Republik Indonesia Tahun 1999 Nomor 165, Tambahan Lembaran Negara Republik Indonesia Nomor 3886)

Undang-Undang Nomor26 Tahun 2000 tentang Pengadilan Hak Asasi Manusia (Lembaran Negara 
Republik Indonesia Tahun 2000 Nomor 208, Tambahan Lembaran Negara Republik Indonesia Nomor 4026)

Peraturan Pemerintah Nomor 2 Tahun 2002 tentang Perlindungan

Korban dan Saksi bagi Pelanggaran Berat Hak Asasi Manusia

Peraturan Pemerintah Nomor 3 Tahun 2002 tentang Kompensasi, Restitusi, dan Rehabilitasi terhadap Korban Pelanggaran Berat Hak Asasi Manusia

\section{Internet}

Ady, Penegakan HAM di Indonesia Memprihatinkan, http:// www.hukumonline.com/berita/baca/ 1t52aa8flb6e $5 \mathrm{~d} /$ penegakan-ham-diindonesia-memprihatinkan

Butje Tampi, Mekanisme Pengaduan dan Pelaporan Terhadap Pelanggaran Hak Asasi Manusoa di Indonesia. SERVANDA_Jurnal Ilmiah Hukum, http://repo.unsrat.ac.id/76/1/ MEKANISME_PENGADUAN DAN_PELAPORAN_TERHADAP PELANGGARAN_HAK_ASASI MANUSIA_DI_INDONESIA.pdf.

Rofiq Hidayat, Vonis Mati Satu Pelaku Pemerkosa Yuyun, Dianggap Belum Memenuhi Rasa Keadilan, http://www.hukumonline.com/berita/ baca/1t57ee193a24fe4/vonis-matisatu-pemerkosa-yuyun--dianggapbelum-memenuhi-rasa-keadilan. 